\title{
Morphological development of 2 warm-season grasses in the Nebraska Sandhills
}

\author{
J.R. HENDRICKSON, L.E. MOSER, K.J. MOORE, AND S.S. WALLER
}

Authors are rangeland scientist, U.S. Sheep Experiment Station USDA-ARS, Dubois, Ida. 83423; professor, Agronomy Department, University of Nebraska, Lincoln. Nebr., 68583; professor, Iowa State University, Ames, Iowa 50011; and assistant dean, Agricultural Research Division, Institute of Agriculture and Nutural Resources, Lincoln, Nebr. 68583. At the time of the research, the senior author was research assistant, Agronomy Department, University of Nebraska, Lincoln, Nebr

\section{Abstract}

Morphological development of grasses has numerous implications to rangeland management including the timing and amount of herbivory. The objective of this study was to quantify the developmental morphology of prairie sandreed [Calamovilfa longifolia (Hook.) Scribn.] and sand bluestem [Andropogon gerardii var. paucipilus (Nash) Fern.] tiller populations. Tiller populations of these 2 grasses were studied for 2 years in the Nebraska Sandhills. Plant development was evaluated using a growth staging system which quantifies the development of tiller populations. A morphological growth index for each species was calculated from either the weighted average of tiller numbers reported as mean stage count (MSC) or tiller weight reported as mean stage weight (MSW) and correlated with the independent variables of growing degree days (GDD) and day of year (DOY). Correlation coefficients with the independent variables were greater than 0.97 for MSC and MSW within years and greater than 0.90 between years. Greater rainfall and warmer temperatures in 1991 increased the number of tillers in the more advanced morphological stages in prairie sandreed, but tiller weight rather than tiller number increased in more advanced stages of sand bluestem. A majority of the harvested tillers were vegetative throughout the sampling period but by the end of the growing season, a wide range of morphological stages were present. The use of grazing to prevent the formation of culmed tillers in these grasses may be unnecessary because of the high proportion of vegetative tillers and the wide range of morphological stages available for selection by livestock

Key Words: phenology, tiller populations, mean stage count, mean stage weight, Calamovilfa longifolia (Hook.) Scribn., Andropogon gerardii var paucipilus (Nash) Fern.

Prairie sandreed [Calamovilfa longifolia (Hook.) Scribn.] is the most uniformly distribuled and abundant species in the Nebraska

\footnotetext{
The authors would like to thank Drs. K. Vogel, A. Frank, W. Wilhelm, W. Schacht and D. Briske for their suggestions on earlier versions of this manuscript.

Published with the approval of the director the Univ. Of Nebraska-Lincoln, Institute of Agriculture and Natural Resources, Agr. Res. Div. as Joumal Ser. No. 11716. U.S. Department of Agriculture, Agricultural Research Service, Northern Plains Area, is an equal opportunity/affirmative action employer and all agency services are available without discrimination.

Manuscript accepted 12 Sept. 1997.
}

\section{Resumen}

El desarrollo morfológico de los pastos tiene numerosas implicaciones en el manejo de praderas incluido el tiempo de pastoreo y la carga animal. El objetivo de este estudio fue la cuantificación del desarrollo morfológico de la población de hijuelos de prairie sandreed [Calamovilfa longifolia (Hook.) Scribn.], del grupo de los zacatones, y popotillo arenoso [Andropogon gerardii var, paucipilus (Nash) Fern.]. La población de hijuelos de estas dos especies fueron estudiadas por dos años en las Sandhills de Nebraska. El desarrollo de las plantas fue evaluado usando un sistema de estados de desarrollo, el cual cuantifica el desarrollo de la población de hijuelos. Un indice de crecimiento morfológico para cada especie fue calculado a partir del promedio ponderado del número de hijuelos reportados como media de cada estado contado (MSC) o peso de los hijuelos reportado como peso promedio de cada estado (MSW) y fue correlacionado con las variables independientes grado de crecimiento en días (GDD) y días del año (DOY). Los coeficientes de correlación con las variables independientes fueron mayores que 0.97 para MSC y MSW dentro de años, $y$ mayor que 0.90 entre años. Las mayores pluviometrías y las temperaturas más cálidas de 1991 incrementaron el número de hijuelos en los estados morfológicos más avanzados en prairie sandreed, pero el peso de los hijuelos, más que el número de éstos, incrementó en los estados más avanzados de popotillo arenoso. A lo largo del periodo de muestreo, la mayoría de los hijuelos fueron cosechados en estado vegetativo, pero al final del periodo de crecimiento se presentó un amplio rango de estados morfológicos. El uso del pastoreo para prevenir la formación de hijuelos en estado reproductivo en estas especies no sería necesario debido a la alta proporción de hijuelos en estado vegetativo y al amplio rango de estados morfológicos disponibles para la selección por parte del ganado.

Sandhills and sand bluestem [Andropogon gerardii var. paucipilus (Nash) Fern.] is an important co-dominant (Burzlaff 1962). These 2 grasses along with little bluestem [Schizachyrium scoparium (Michx.) Nash] make up 60\% of the upland plant community in the Nebraska Sandhills. Prairie sandreed develops rapidly in May and June and flowers from July to September (Tolstead 1942). Prairie sandreed also produces some biennial 
tillers which are initiated in the summer and resume growth early the following spring (Brejda et al. 1988). Sand bluestern begins growth in May and flowers from the first week of July to September. The extent of reproductive growth in sand bluestem is determined by the amount of rainfall (Tolstead 1942). Sand bluestem may develop lateral inflorescences but usually these occur later than the terminal inflorescence (Sims et al. 1973). Tillering in sand bluestem appears to be under strong control of the parental tiller and is usually limited unless the parent tiller is defoliated or senesces (Sims et al. 1973, Brejda et al. 1988),

In grasses, developmental morphology determines plant architectural organization, influences accessibility and palatability to herbivores, and affects regrowth following defoliation (Briske 1991). Developmental processes are affected by both genetic and environmental variables. Air temperature was found to be the primary environmental variable regulating morphological development in westem wheatgrass [Pascopyrum smithii Rydb.(Löve)], blue grama [Bouteloua gracilis (H.B.K.)Lag. ex. Griffiths], needleandthread (Stipa comata Trin. and Rupr.), and prairie junegrass [Koeleria pyramidata (Lam.)Beauv.] (Frank and Hofmann 1989). However, day of the year predicted leaf development as well as accumulated growing degree-days in little bluestem and big bluestem [Andropogon gerardii Vitman] (Gillen and Ewing 1992). Both growing degree day (GDD) and day of the year (DOY) appear to be valuable predictors of grass morphological development.

Indices used in previous research on grass morphological development, often did not evaluate actual tiller populations. Moore et al. (1991) developed a system of growth staging that quantified the morphology of tiller populations rather than individual tillers or a selected group of tillers. By examining tiller populations, this system evaluates a more representative sample and should predict the morphology of available forage more accurately than previously used growth staging systems (ie. Haun 1973; Simon and Parks 1983).

The objective of this study was to quantify the developmental morphology of tiller populations of prairie sandreed and sand bluestem relative to GDD and day of year using the growth index described by Moore et al. (1991). These grasses are major components of the vegetation of the region and heavily utilized by grazing animals (Northup 1993). Knowledge of grass morphology is essentitial for designing grazing systems and understanding the impact of grazing on vegetative communities occurring in the Nebraska Sandhills.

\section{Materials and Methods}

Prairie sandreed and sand bluestem tiller populations were studied for 2 years at the University of Nebraska Gudmundsen Sandhills Laboratory (GSL) near Whitman, in the Nebraska Sandhills. The soil was a Valentine fine sand (mixed, mesic Typic Ustipsamment) and study areas were dominated by prairie sandreed and sand bluestem. These 2 grasses made up greater than $70 \%$ of the hiomass in the study areas. A mixture of forbs and other grasses, including little bluestem, prairie junegrass and switchgrass (Panicum virgatum L.), comprised the remaining vegetation. The study areas were in good range condition. Average annual precipitation at the laboratory site is $514 \mathrm{~mm}$.
In April 1990, 12 blocks, ranging in size from $20 \times 20 \mathrm{~m}$ to 30 $\times 50 \mathrm{~m}$, were located within a $2-\mathrm{km}$ radius. Block size was determined by the species composition and terrain homogeneity. All blocks were located on sands range sites that were not grazed during the sampling period. In April 1991, 8 similar ungrazed blocks were located on sands sites within a $2 \mathrm{~km}$ radius. Sampling began on 15 May 1990, and continued at approximately 10-day intervals until 24 Aug. 1990. Sand bluestem was not sufficiently developed for sampling at the first date in 1990 but was sampled on subsequent harvest dates. Sampling started 20 May and continued, at 10-day intervals, until 21 Aug. 1991.

At the start of each season, 12 transects were permanently marked, within each block, to aid in sample location. Samples were located by randomly choosing a transect and a random point along the transect. A $1-\mathrm{m}^{2}$ quadrat was placed on the random point and all tillers of a target species within the quadrat were clipped leaving a $3 \mathrm{~cm}$. stubble. This procedure was repeated, within a block, until approximately $20 \mathrm{~g}$ (fresh weight) of a target species were collected. This was usually 40 to 60 tillers. Complete quadrats were clipped even if the minimum tiller number was reached prior to completion of clipping. After a quadrat was sampled, the area was marked so it would not be resampled at a later harvest. Each of the target species was sampled in this manner in all blocks at all dates. This sampling regime was carried out in both years, although in 1991, a minimum of 2 quadrats was harvested even if the minimum tiller number was reached in the first quadrat. Because of the variable number of quadrats needed to obtain the minimum quadrat and tiller numbers for each species, not all the transects were sampled on each harvest. A range of 5 to 10 transects was usually sampled within each block during each harvest.

Developmental morphology of the tiller population was estimated using the mnemonic scale described by Moore et al. (1991). The system categorizes the life cycle of individual grass tillers into 5 primary growth stages: 0) germination, 1) vegetative, 2) transition, 3) reproductive, and 4) seed ripening but the germination growth stage was not applicable in our study. Each primary stage contains substages that describe specific events common to most grasses. An individual growth stage consists of a primary and substage and has a mnemonic and numerical index associated with it. This growth staging system is described in greater detail in Moore et al. (1991).

If more than $50 \%$ of a leaf was dead, it was not included when determining morphological stages (Moore et al. 1991). Events were recorded in the elongation stage only if the nodes were palpable in the field. Node determination in prairie sandreed required peeling back the leaf sheaths because the large, thick sheaths obscured the nodes. Sand bluestem nodes were more exposed and were easily located.

Some prairie sandreed inflorescences emerged from the side of the sheath while the tops of the seedheads were still wrapped in the flag leaf. Once the seedhead emerged from either the side or the top of the sheath, the tiller was considered to be in the inflorescence emergence stage. Since sand bluestem had multiple inflorescences, the stage of development was based on the most advanced inflorescence which was generally the terminal inflorescence. Seed ripening stages (SR) were difficult to classify especially in the smaller seeded prairie sandreed.

Tillers of each stage were counted and placed in separate sacks in the field and later dried at $55^{\circ} \mathrm{C}$. The quantitative growth 
indices (Moore et al. 1991) were computed at the conclusion of the growing season by determining the total number of morphological events in the vegetative and transition stages. The mean stage by count (MSC) was calculated using the following working formula:

$$
M S C=\sum_{\mathrm{i}=0}^{4.9} \frac{\mathrm{S}_{\mathrm{i}} \times \mathrm{N}_{\mathrm{i}}}{\mathrm{C}}
$$

Where:

$\mathrm{Si}=$ growth stage, 0 to 4.9

$\mathrm{Ni}=$ number of tillers in stage $\mathrm{Si}$

$\mathrm{C}=$ total number of tillers

The mean stage weight (MSW) value is calculated by replacing $N$ with the dry weight of tillers in stage $S_{i}$ and $C$ with the total dry weight of all the tillers.

The standard deviation of the mean stage by count $\left(S_{m s c}\right)$, which estimates the amount of variation around the MSC, was estimated using the following equation:

$$
S_{m s c}=\sqrt{\sum_{i=0}^{4.9}\left(S_{i}-M S C\right)^{2} X N_{i}}
$$

The $S_{m s c}$ is useful in interpreting the variability in maturity that exists within a grass stand (Moore et al. 1991). If the tiller numbers in an advanced sub-stage of the vegetative or elongation stages were less than $1 \%$ of the total tillers collected in that stage, the tillers were then included in the next lower substage.

Daily growing degree days (GDD) were calculated as $\left[\left(\mathrm{T}_{\max }+\right.\right.$ $\left.\left.T_{\min }\right) / 2\right]-T_{B}$ where $T_{\max }$ was the maximum daily air temperature, and $T_{\min }$ was the minimum daily air temperature with a lower limit of $10^{\circ} \mathrm{C}$ and $\mathrm{T}_{\mathrm{B}}$ was equal to $10^{\circ} \mathrm{C}$. Accumulated GDD were calculated by summing daily GDD from 1 January of each year. This formula is similar to the formula proposed by Russelle et al. (1984) but without the maximum temperature limit of $30^{\circ} \mathrm{C}$. Morphological development of switchgrass in response to cumulative GDD has been evaluated without an upper temperature maxima (Sanderson and Wolf 1995a,1995b). We felt the assumption of a broad temperature maxima was also appropriate for the $2 \mathrm{C}_{4}$ grasses we studied. Weather data were collected electronically at laboratory headquarters, which was located within $2 \mathrm{~km}$ of all the plots. Thirty-year averages were taken from the closest U.S. Weather Bureau station, which was located $20 \mathrm{~km}$ northeast of the research site. Correlation coefficients were calculated using the correlation procedure in the SAS (1985) statistical program on the means for each sampling date

\section{Precipitation and Growing Degree Days}

Precipitation for 1990 was $351 \mathrm{~mm}$ which was $64 \%$ of normal. Precipitation during the sampling period of May, June, July, and August was $251 \mathrm{~mm}$ or $76 \%$ of the normal for that period. In 1991, the annual precipitation was $526 \mathrm{~mm}$ or $95 \%$ of normal. Precipitation for the sampling period of May through August was $353 \mathrm{~mm}$ or $110 \%$ of normal. Valentine fine sands have low water holding capacities $\left(0.18-0.23 \mathrm{~cm} \mathrm{~cm}^{-1}\right)$ which makes frequency of precipitation more important than total amount. Although 1990 was drier than 1991, rain showers that did occur were minimal but more frequent throughout the growing season in 1990 (Fig. 1).
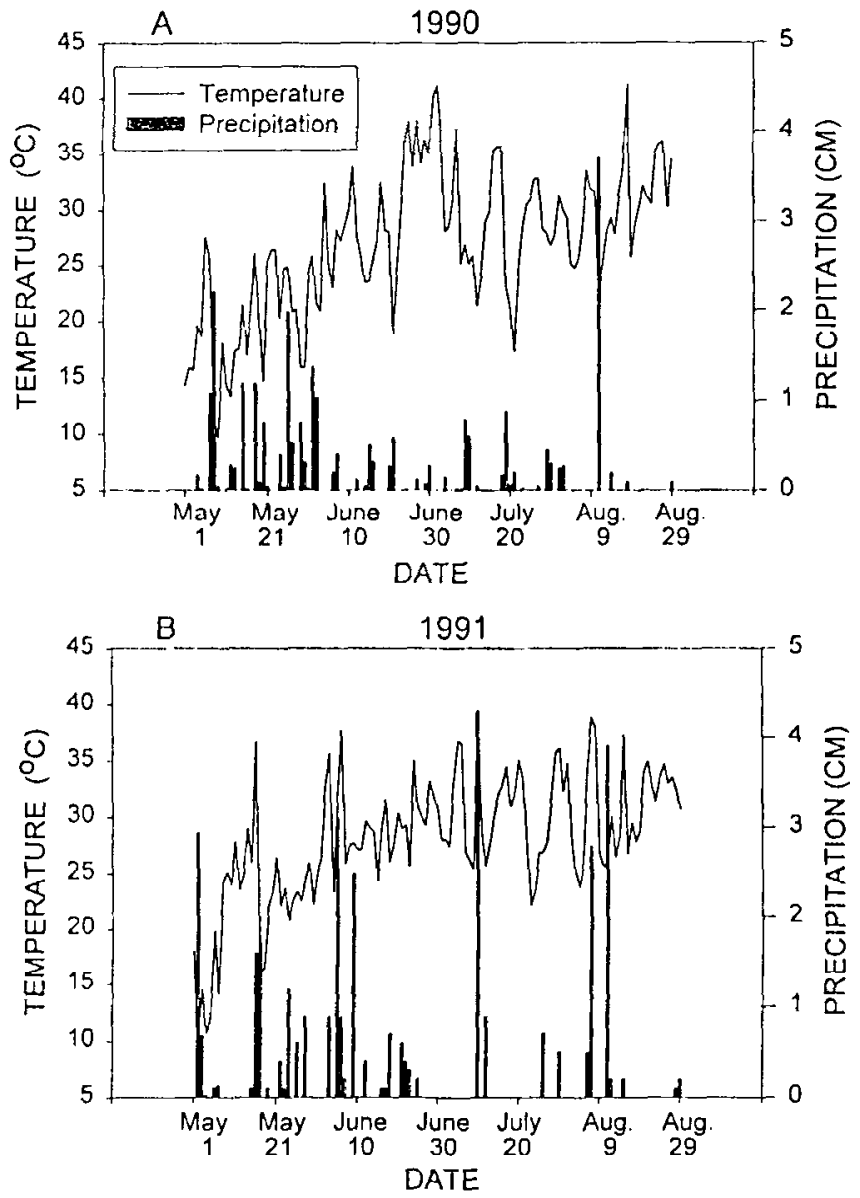

Fig. 1. Precipitation and daily high temperatures from 1 May to 1 Sept. in 1990 (a) and 1991 (b) for the Gudmundsen Sandhills Laboratory, Whitman, Nebr.

Fewer growing degree days (GDD) had accumulated up to start of sampling in 1990 than in 1991 (382 vs. 538 GDD) and each sampling date in 1991 had greater accumulated GDD than equivalent dates in 1990. In both years, accumulated GDD at the start of sampling, was greater than normal (302 GDD)

\section{Results and Discussion}

Prairie sandreed started growth earlier and had more rapid early season development than sand bluestem in both years (Figs. 2, 3). This is consistent with earlier reports from the Sandhills (Tolstead 1942). Morphological development (MSC and MSW) for each species was strongly correlated with GDD and DOY in both years (Table 1), but MSW increased at a faster rate than MSC (Figs. 2, 3). The MSW index, averaged over both species and years, increased 0.125 index units every 10 days compared to a 0.07 index unit increase in the MSC index. Differences between the 2 indices were especially pronounced later in the growing season. After elongated tillers were detected, the MSW index increased 0.15 index units and the MSC index increased 0.08 index units every 10 days compared a 0.08 and 0.06 index unit increase every 10 days prior to tiller elongation for MSW and MSC respectively. The heavier tillers in the more advanced 
Table 1. Correlation coefficients (r) of the growth indices, mean stage by count (MSC) and mean stage by weight (MSW), with growing degree day (GDD) and day of the year (DAY) for prairie sandreed and sand bluestem in 1990, 1991 and combined over both years.

\begin{tabular}{llll}
\hline Species & Growth Index & GDD & DOY \\
\hline 1990 & & & \\
Sand Bluestem & MSC & 0.98 & 0.99 \\
& MSW & 0.98 & 0.98 \\
Prairie Sandreed & MSC & 0.99 & 0.98 \\
& MSW & 0.97 & 0.97 \\
1991 & & & \\
Sand Bluestem & MSC & 0.99 & 0.99 \\
& MSW & 0.99 & 0.98 \\
Prairie Sandreed & MSC & 0.99 & 0.99 \\
& MSW & 0.99 & 0.99 \\
1990-1991 & & & \\
Sand Bluestem & MSC & 0.98 & 0.98 \\
\multirow{2}{*}{ Prairie Sandreed } & MSW & 0.98 & 0.96 \\
& MSC & 0.96 & 0.91 \\
& MSW & 0.98 & 0.94 \\
\hline
\end{tabular}

growth stages made up an increasingly greater percentage of the biomass as the season progressed (Figs. 4B, 4D, 5B, 5D) and therefore influenced MSW more than MSC. Although MSW progressed at a faster rate than MSC, both indices were highly correlated with each other $(r=.99)$ for both species in both years.

The strong correlation of morphological development with both accumulated GDD and DOY is supported by Gillen and Ewing

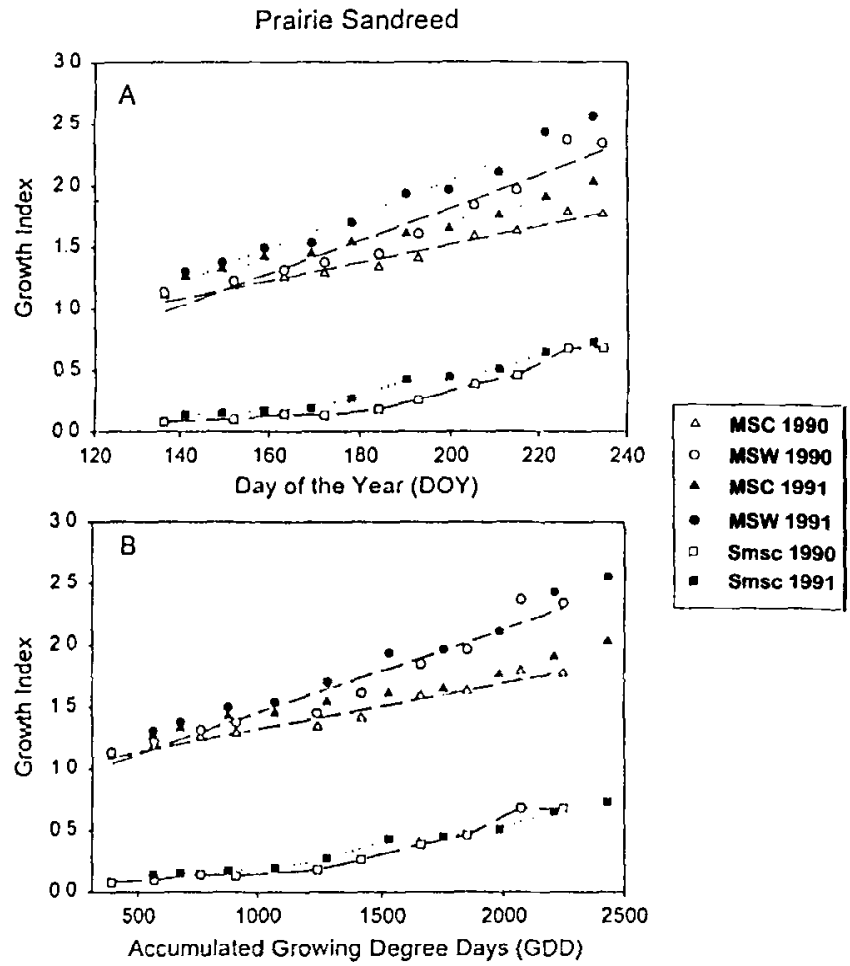

Fig. 2. Mean Stage by Count (MSC), Mean Stage by Weight (MSW) growth indices and standard deviation of MSC $\left(\mathrm{S}_{\text {msc }}\right)$ related to day of the year (a) and accumulated growing degree days (b) for prairie sandreed in 1990 and 1991.

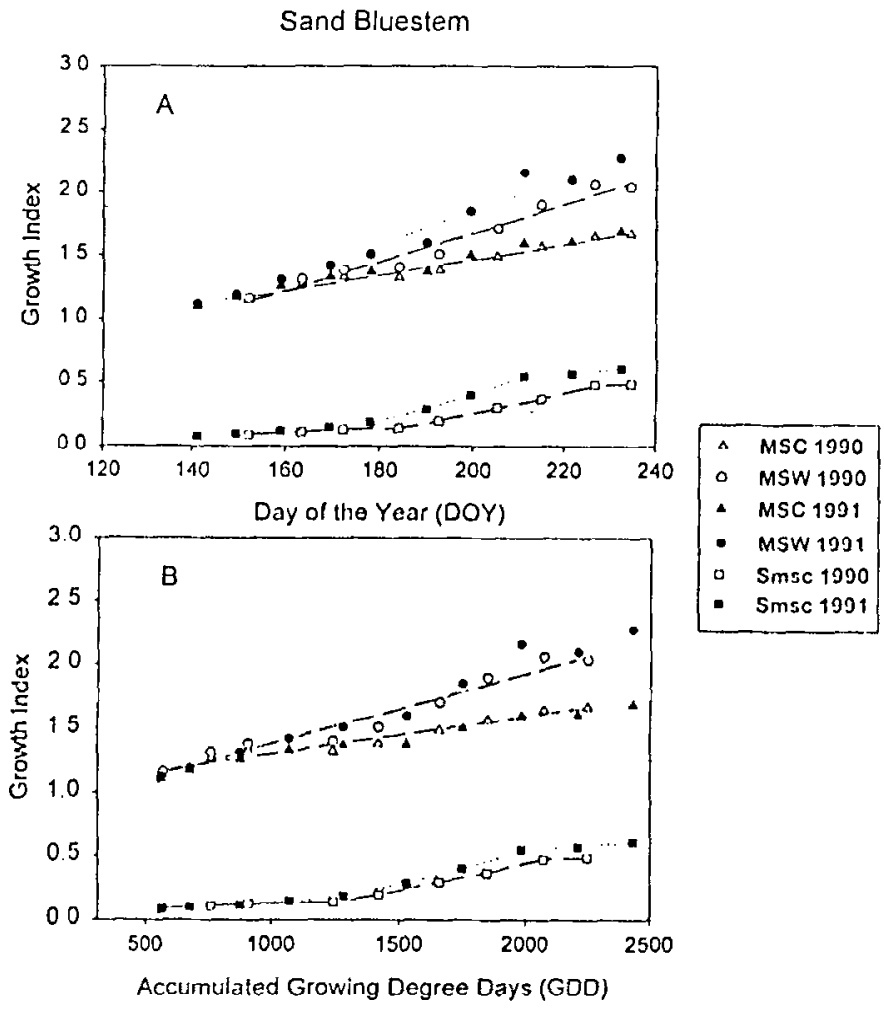

Fig. 3. Mean Stage by Count (MSC), Mean Stage by Weight (MSW) growth indices and standard deviation of MSC $\left(S_{\text {msc }}\right)$ related to day of the year (a) and accumulated growing degree days (b) for sand bluestem in 1990 and 1991.

(1992) who found that DOY predicted leaf development as well as GDD in big and little bluestem. Although GDD and DOY had similar correlation coefficients, increased GDD accumulation and greater precipitation resulted in the MSW growth index of both species being more advanced at the end of the season in 1991 than in 1990 (Figs. 2, 3). In prairie sandreed especially, the more advanced end of season growth indices in 1991 were determined more by a higher initial growth index than by faster development during the growing season. Over the 1991 sampling period, prairie sandreed developed at the same rate as in 1990 per 100 GDD (MSC $=0.04$ index units, MSW $=0.07$ index units) and a similar rate of development per 10 calendar days (1990 MSC = 0.07 index units, MSW $=0.12$ index units; 1991 $\mathrm{MSC}=0.08$ index units, MSW 0.14 index units). However, the initial growth indices for prairie sandreed were higher in 1991 than in 1990 $(1990 \mathrm{MSC}=1.11, \mathrm{MSW}=1.14 ; 1991 \mathrm{MSC}=1.27, \mathrm{MSW}=$ 1.31).

Growth indices have been used to evaluate morphological development and determine the grazing readiness of grasses. For example, Frank and Hoffman (1989) related grazing readiness, as determined by the Haun scale (1973), to GDD and developed a practical method for predicting grazing readiness of native grasses in the Northern Great Plains. In the Nebraska Sandhills, warmseason grass utilization generally begins around 1 June (P. Reece personal communication). Development in sand bluestem prior to 1 June was more consistently related to DOY than GDD. By 30 May 1990, sand bluestem had a MSC growth index of 1.15 which 
1990

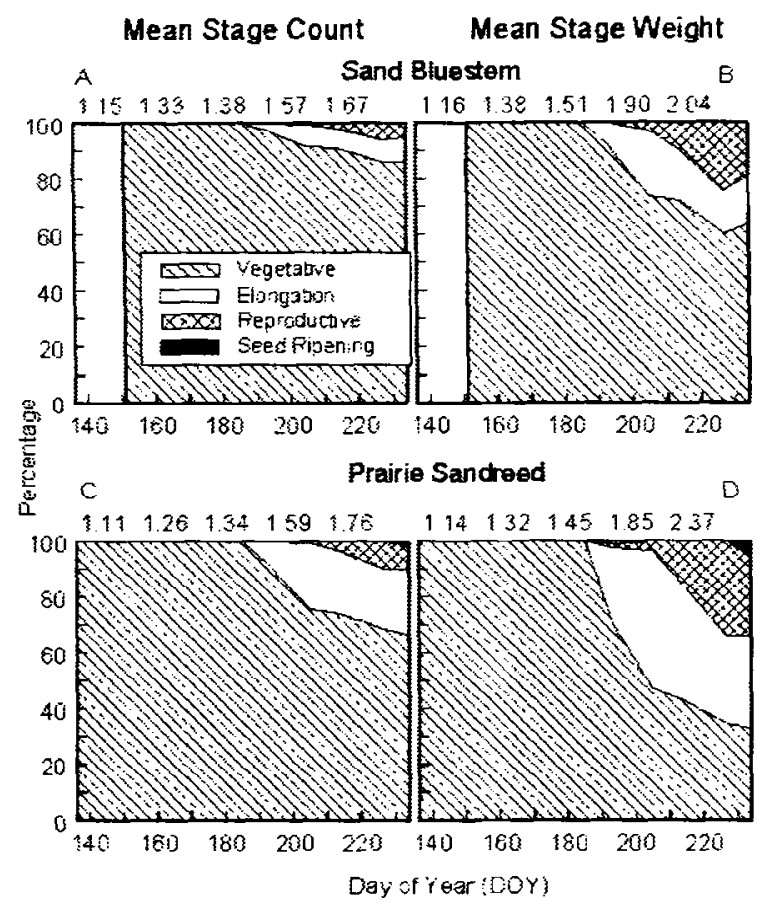

Fig. 4. Percent of harvested tillers in the vegetative, elongated, reproductive and seed ripening growth stages that contributed to Mean Stage Count (A) and Mean Stage Weight (B) in sand bluestem and Mean Stage Count (C) and Mean Stage Weight (D) in prairie sandreed in 1990.

was similar to the MSC growth index (1.17) on 29 May 1991. However, accumulated GDD prior to 1 June was 140 GDD more in 1991 than in $1990(1991 \mathrm{GDD}=678,1990 \mathrm{GDD}=536)$.

In contrast, development of prairie sandreed prior to 1 June was not consistently related to DOY. Prairie sandreed had a MSC growth index of 1.19 on 30 May 1990 compared to 1.33 on 29 May 1991. Faster accumulation of GDD and increased precipitation during the first half of April 1991 would have contributed to the more rapid development of prairie sandreed in 1991. Although increased GDD accumulation apparently contributed to more rapid early season development in prairie sandreed, accumulated GDD could not be consistently related to individual MSC values later in the season. For example, prairie sandreed took an additional $200 \mathrm{GDD}$ to reach an MSC value of 1.27 in 1990 than in 1991. The relationship between GDD and early season development was inconsistent for both species and more research is needed to determine the grazing readiness of these grasses. The growth index designed by Moore et al. (1991) provided a fast and accurate assessment of the morphological development of tiller populations of these 2 grasses. These attributes make it an excellent tool for evaluating morphological status relative to grazing readiness, forage quality, or environmental influences on development.

The growth indices stabilized during the interval between the last 2 harvests in 1990 (Figs. 2, 3) because of increased leaf senescence. The period 13-21 Aug. 1990 was characterized by several days of high temperatures (daily high temperatures $>33^{\circ}$ C) which combined with decreased August precipitation ( $72 \%$ of normal) to increase leaf senescence. Both mean stage count

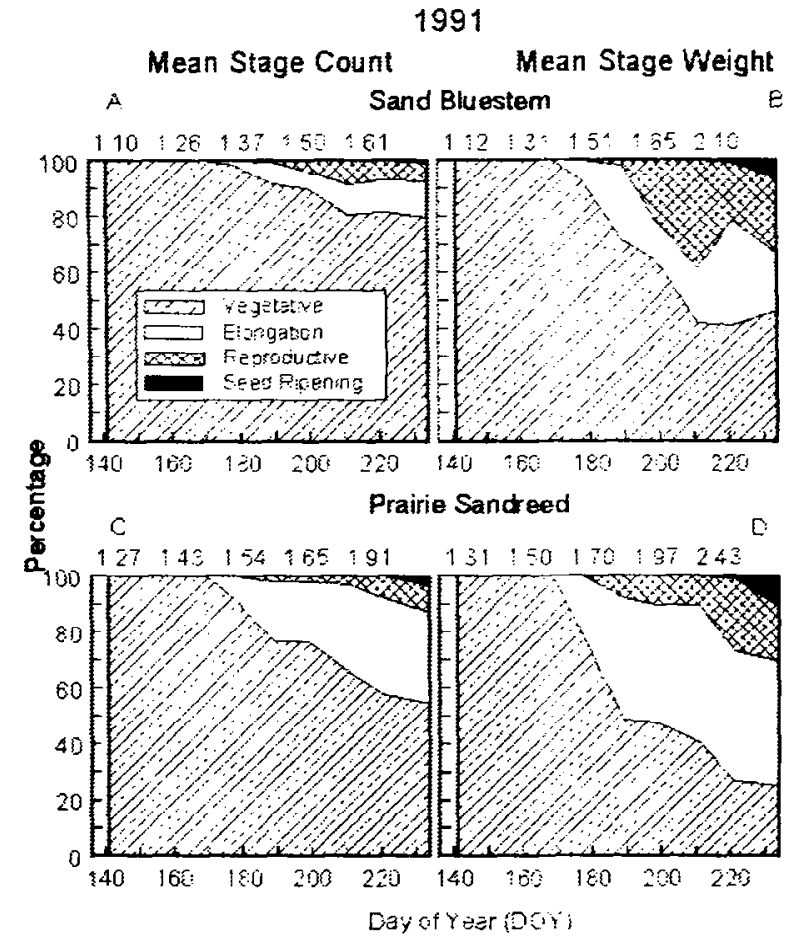

Fig. 5. Percent of harvested tillers in the vegetative, elongated, reproductive and seed ripening growth stages that contributed to Mean Stage Count (A) and Mean Stage Weight (B) in sand bluestem and Mean Stage Count $(C)$ and Mean Stage Weight $(D)$ in prairie sandreed in 1991.

(MSC) and mean stage weight (MSW) only use leaves present on the stem when it is harvested and so it is possible for the growth indices to stabilize or decline when leaf sensence is high. This is especially true when there are large numbers of vegetative tillers as with the populations of these 2 species. The more succulent leaves of sand bluestem may be more sensitive to stress and senesce more readily than prairie sandreed leaves. In 1990, the MSC index for sand bluestem did not increase from 800 to 1,150 GDD (approximately late June 1990) (Fig. 3) reflecting increased leaf senescence. Daily high temperatures during this period (> $32^{\circ} \mathrm{C}$ ), including several days in excess of $38^{\circ} \mathrm{C}$ (Fig. 1A), combined with low precipitation $(5 \mathrm{~mm})$ to increase leaf senescence in sand bluestem more than in prairie sandreed.

Both species responded differently to the increased precipitation and more rapid GDD accumulation in 1991 compared to 1990. Prairie sandreed had a larger proportions of tillers in advanced substages in 1991 (Figs. 4C, 5C) but the advanced tillers had lower mean individual tiller weights than in 1990 $\left(1990=1.05 \mathrm{~g} \mathrm{tiller}^{-1}, 1991=0.76 \mathrm{~g}\right.$ tiller $\left.^{-1}\right)$. Higher numbers of smaller tillers in the more advanced growth stages caused both growth indices for prairie sandreed to be 10 to $15 \%$ higher at the end of the season in 1991 compared to 1990. In contrast to prairie sandreed, the MSC index for sand bluestem was relatively constant hetween years (Fig. 3) indicating there was a similar proportion of tillers in all growth stages in both years. Sand bluestem responded to improved growing conditions in 1991 by increasing tiller weights in the more advanced growth stages. This interpretation is supported by a more advanced MSW index in 1991 than in 1990 (Fig. 3), a declining contribution of vegetative tillers to biomass in the MSW index in 1991 compared to 1990 (Figs. 
$4 \mathrm{~B}, 5 \mathrm{~B})$ and increased mean tiller weights for the elongated tillers in 1991 ( $\left.1.05 \mathrm{~g} \mathrm{tiller}^{-1}\right)$ compared to 1990 ( $\left.0.91 \mathrm{~g} \mathrm{tiller}^{-1}\right)$.

The improved growing conditions in 1991 resulted in some morphological stages being observed in 1991 that were either not present in 1990 or occurred earlier in 1991 than in 1990. For example, prairie sandreed tillers in the elongation stage were observed approximately 2 weeks earlier in 1991 and their numbers increased more rapidly than in 1990 (Figs. 4C, 5C). Improved growing conditions in 1991 may have accelerated development and caused a faster rate of growth in internodal intercalary meristems and therefore an earlier detection of culm elongation. It should be noted, however, that detection of palpable nodes does not indicate initiation of culm elongation but rather the point when culm elongation is readily detectable. Better growing conditions in 1991 also resulted in some sand bluestem tillers entering the seed ripening stage of development in 1991 (Fig. 5A) but not in 1990 (Fig. 4A).

Although there were differences in morphological development between species, a majority of the harvested tillers were vegetative (growth index 1.0-2.0) in both years (Figs. 4A, 4C, 5A, 5C). This was apparent in sand bluestem where, even late in the season, approximately $80 \%$ of the tillers collected were in the vegetative stage (Figs. 4A, 5A). Tiller populations for prairie sandreed had a smaller percentage of vegetative tillers late in the growing season, but still more than $50 \%$ of the tillers were vegetative (Figs. 4C, 5C). However, the contribution of vegetative tillers to biomass was more limited. In prairie sandreed, vegetative tillers contributed about $25 \%$ to the MSW index by the end of the season in 1991 (Fig. 5D). This trend was also apparent in sand bluestem, although vegetative tillers still contributed more than $40 \%$ to MSW (Fig. 5B). Still, tillers with 3 nodes or less contributed a majority of the weight in the elongated growth stage in both species. When combined with the weight of the vegetative tillers, a majority of the biomass, even late in the season, was comprised of vegetative tillers or elongated tillers in the early stages of development which are readily grazed by livestock (Figs 4B, 4D, 5B, 5D).

Forage availability to livestock may be affected by the differences in species responses to growing conditions. Morphological advancement of prairie sandreed in 1991 resulted in a higher percentage of culmed and reproductive tillers compared to 1990 (Fig. 4C, 5C). Greater numbers of reproductive tillers have been identified as a grazing avoidance mechanism in caespitose grasses (Ganskopp et al. 1992, Truscott and Currie 1989, Willms et al. 1980) although this does not seem to be true for the rhizomatous prairie sandreed. Prairie sandreed in this area has previously been reported to be selected at a high and consistent level by yearling steers (Northup 1993) despite its relatively low nutritive value (Hendrickson et al. 1997). Abundance, availability and frequency of encounters may result in the relatively high selection of prairie sandreed (Northup 1993) and culmed tillers may not be concentrated enough to deter herbivory.

A wide range of morphological stages influences animal selection. In the growth staging systern developed by Moore et al. (1991), $S_{\text {msc }}$ estimates the morphological diversity in a tiller population. The $S_{\mathrm{msc}}$ increased as morphological development advanced which indicated morphologically advanced tiller populations for these 2 species contained a wide variety of morphological stages (Figs. 2, 3). The first sampling date generally had about 4 separate sub-stages but at the end of the growing season as many as 20 separate sub-stages were present in some popula- tions. The wide range of morphological stages (high $\mathrm{S}_{\mathrm{msc}}$ ) would allow livestock to select a diet high in vegetative tillers even relatively late in the growing season.

The reproductive stage (seed head development) occurred at approximately the same date (mid-July) in both years and species. Onset of the seed ripening occurred sooner in 1991 than in 1990 for prairie sandreed (Fig. 4C, 4D, 5C, 5D). In 1990, no sand bluestem tillers reached the seed ripening growth stage; however, some tillers reached this stage in 1991 (Figs. 4A, 5A). In prairie sandreed, only 40 growing degree days (GDD) separated the timing of seed ripening between years. Sand bluestem entered the seed ripening stage at the same time as prairie sandreed in 1991. The timing of these 2 events was consistent with the previously reported development of these species in the Nebraska Sandhills (Tolstead 1942) but occurred earlier than for reports for sand bluestem from Colorado (Sims et al. 1973).

The number of tillers in the seed ripening stage was relatively small in both years. Only the final harvest date in 1990 and the final 2 harvest dates in 1991 had appreciable numbers of tillers in the seed ripening stage and these comprised less than $5 \%$ of the tillers collected in those harvest periods (Fig. 5). Early reports (Tolstead 1942) indicated seed production rarely occurred in mature stands of these species such as those present at the research site. The lack of reproductive development in these grasses is consistent with investigations into seed banks of North American grasslands which have demonstrated a lack of correspondence between composition of seed banks and aboveground vegetation (Johnson and Anderson 1986, Coffin and Lauenroth 1989, Kinucan and Smeins 1992). Vegetative reproduction appears to be the primary method of propagation in perennial grasses in these systems.

Both GDD and day of year (DOY) were equally related to morphological development of the tiller populations of these 2 grasses within a year. Accumulated GDD would incorporate temperature variations and theoretically should have a better relationship over several years. Data from prairie sandreed supports this conclusion. Each species responded differently to improved plant growth conditions in 1991. Prairie sandreed increased the number of tillers in the more advanced stages while sand bluestem increased tiller weights in the more advanced stages. In both species, more than $50 \%$ of the end of season biomass was comprised of tillers in the vegetative and early elongation stages. Since morphological advancement has a relatively limited influence on leaf nutritive valuc (Hendrickson et al. 1997) and most tillers in these grasses had not advanced past the early elongation stage, increasing grazing pressure to prevent these 2 species from forming culmed tillers may not be needed on rangelands dominated by these grasses.

\section{Literature Cited}

Brejda, John J., Lowell E. Moser, and Steven S. Waller. 1988. Rhizome and tiller development of three Nebraska Sandhills warm-season grasses. p. 52. In: Thomas B. Bragg and James Stubbendieck (eds.), Proc. 11 th North American Prairie Conference. University of Nebraska Printing, Lincoln, Nebr.

Briske, D.D. 1991. Developmental morphology and physiology of grasses. p. 85-108. In: Rodney K. Heitschmidt and Jerry W. Stuth (eds.). Grazing management: An ecological perspective. Timber Press, Portland, Ore. 
Burzlaff, Donald F. 1962. A soil and vegetation inventory andanalysis of three Nebraska Sandhills range sites. Univ. of Nebr. Agr. Exper. Stat. Res. Bull. 206.

Coffin, D.P. and W.K. Lauenroth. 1989. Spatial and temporal variation in the seed bank of a semiarid grassland. Amer. J. Botany 76: 53-58.

Frank, A.B. and L. Hofmann. 1989. Relationship among grazing management, growing degree-days, and morphological development for native grasses on the Northern Great Plains. J. Range Manage. 42: 199-202.

Ganskopp, David, Ray Angell, and Jeff Rose. 1992. Response of cattlc to cured reproductive stems in a caespitose grass. J. Range Manage. 45:401-404.

Gillen, Robert L. and Anne L. Ewing. 1992. Leaf development in native bluestem grasses in relation to degree-day accumulation. $J$. Range Manage. 45: 200-204.

Haun, J.R. 1973. Visual quantification of wheat development. Agron. J. 65:116-119.

Hendrickson, J.R., L.E. Moser, K.J. Moore and S.S. Waller. 1997. Leaf nutritive value related to tiller development in warm-season grasses. J. Range Manage. 50: 116-122.

Johnson, R.G. and R.C. Anderson. 1986. The seed bank of a tall grass prairie in Illinois. The Amer. Midl. Nat. 115:123-130.

Kinucan, R.J. and F.E. Smeins. 1992. Soil seed bank of a semiarid Texas Grassland under three long-term (36 years) grazing regimes. The Amer. Midl. Nat. 128:11-21.

Moore, K.J., L.E. Moser, K.P. Vogel, S.S. Waller, B.E. Johnson, and J.F. Pederson. 1991. Describing and quantifying growth stages of perennial forage grasses. Agron. J. 83:1073-1077.
Northup, B.K. 1993. Utilization of native forages of the Nebraska Sandhills by yearling cattle. Ph.D. dissertation, University of Nebraska, Lincoln, Nebr.

Russelle, M.P., W.W. Wilhelm, R.A. Olson, and J.F. Power. 1984 Growth analysis based on degree days. Crop Sci. 24: 28-32.

Sanderson, M.A. and D.D. Wolf. 1995a. Morphological development of switchgrass in diverse environments. Agron. J. 87: 908-915.

Sanderson, M.A. and D.D. Wolf. 1995b. Switchgrass biomass composition during morphological development in diverse environments. Crop Sci. 35:1432-1438.

SAS Institute Inc. 1985. SAS user's guide: Statistics, Version 5 edition. SAS Institute Inc., Cary, N.C.

Simon. U. and B.H. Park. 1983. A descriptive scheme for stages of development in perennial forage grasses. p. $416-418$. In: J.A. Smith and V.W. Hays (eds.) Proc. 14th Int. Grassl. Congr., Lexington, Ky. Westview Press. Boulder, Colo.

Sims, Phillip, Robert K. Lang'at, and D.N. Hyder. 1973. Developmental morphology of blue grama and sand bluestem. J. Range Manage. 26: 340-344.

Tolstead, W.L. 1942. Vegetation of the northern part of Cherry County, Nebraska. Ecol. Monogr. 12:255-292.

Truscott, Doreen R. and Pat O. Currie. 1989. Cattle preferences for a hybrid grass: chemical and morphological relationships. J. Range Manage. 42:22-27.

Willms, W., A.W. Bailey, and A. McLean. 1980. Effect of burning. or clipping Agropyron spicatum in the autumn on the spring foraging behaviour of mule deer and cattle. J. of Appl. Ecol. 17: 69-84. 